\title{
DEVELOPING SHARIA TOURISM IN FOSTERING REGIONAL ECONOMIC GROWTH (STUDY ON SHARIA TOURISM AT WEST NUSA TENGGARA)
}

\author{
Ibnu Elmi A.S Pelu, Rahmad Kurniawan, Wahyu Akbar \\ State Islamic Institute of Palangka Raya \\ Email: ibnu.elmi@iain-palangkaraya.ac.id, \\ iwankeren52@gmail.com/rahmad.kurniawan@iain-palangkaraya.ac.id, \\ wahyu.akbar@iain-palangkaraya.ac.id
}

\begin{abstract}
The study investigated the development of sharia tourism to encourage the growth of potential tourist destination improve the regional economy as a sharia tourism destination, as well as legal policies in fostering sharia tourism in West Nusa Tenggara. The study employed qualitative research approach using concept of sharia tourism, the legal approach, and the sharia economic contextual approach. The findings revealed that: (1) from the road map view, Sharia tourism carried out by West Nusa Tenggara Provincial government was a


continuation of sharia tourism by establishing 99 sharia tourism villages having local wisdom. In addition, developing sharia tourism was done by performing itself as a sharia tourist destination that did not ignore other tourism. It was also an avenur for a particular tourism choice in West Nusa Tenggara. The sharia tourism was considered successful in attracting foreign tourist destination, especially tourists from Muslim countries and some attractive Investment. The development of sharia tourism also tend to increase positively toward economic growth at West Nusa Tenggara. This can be seen from the data released by West Nusa Tenggara Tourism Department and Bank Indonesia, which showedeconomic growth of this region without mining sector in 2016 has reached $5.72 \%$ increase, in 2017 up to $7.10 \%$, and in 2018, despite the earthquake, it continued to increase to $7.23 \%$ year. (2) from the view of legal policies, West Nusa Tenggara already has strong legal legitimacy, so it can guarantee legal certainty in developing Sharia tourism destination. So hat, Sharia tourism destination in West Nusa Tenggara have clear policy directions in their ideas. It was strongly supported by policies, and implemented gradually.

Keyword: Developing, Sharia Tourism, West Nusa Tenggara

\begin{abstract}
Abstrak
Penelitian ini membahas tentang pengembangan pariwisata halal untuk mendorong dan meningkatkan kunjungan wisatawan dan meningkatkan ekonomi daerah bagi Provinsi Nusa Tenggara Barat sebagai destinasi wisata halal. Serta kebijakan hukum dalam pengembangan wisata halal di kawasan Nusa Tenggara Barat. Penelitian ini menggunakan penelitian kualitatif dengan pendekatan konsep pariwisata halal, pendekatan perundang-undangan, pendekatan kontekstual ekonomi syariah. Hasil penelitian ini menunjukkan Pertama dari sisi road map wisata halal yang dilakukan oleh pemerintah Provinsi Nusa Tenggara Barat mengembangkan kelanjutan dari pariwisata halal yang sudah ada dengan mencanangkan 99 desa wisata halal yang berkeearifan lokal. Selain itu pengembangan pariwisata syariah dengan menampilkan diri sebagai destinasi wisata halal yang tidak mematikan wisata lainnya dan juga merupakan sebuah wahana model produk pilihan secara khusus yang ada di Nusa Tenggara Barat dianggap berhasil dapat menarik kunjungan wisatawan mancanegara terutama wisatawan dari negara Muslim dan menarik investasi.Perkembangan wisata halal juga mengalami peningkatan yang positif terhadap pertumbuhan ekonomi di Provinsi NTB, setidaknya terlihat dari data yang dirilis Dinas
\end{abstract}


Pariwisata NTB dan dari data Bank Indonesia yang menyebutkan pertumbuhan ekonomi daerah ini tanpa sektor tambang pada tahun 2016 mencapai 5,72 \%/tahun meningkat tahun 2017 mencapai 7,10\% Itahun dan pada tahun 2018 meskipun terjadi gempa tetap meningkat menjadi 7,23 \%/tahun. Kedua dari sisi kebijakan hukum yang ada di Nusa Tenggara Barat sudah mempunyai legitimasi hukum yang kuat, sehingga bisa menjamin kepastian hukum dalam pengembangan destinasi pariwisata halal. Sehingga destinasi pariwasata halal yang ada di Nusa Tenggara Barat arah kebijakannya jelas dalam gagasannya, sangat didukung oleh kebijakan, dan bertahap dalam implementasi.

Keyword: Pengembangan, Wisata Halal, Nusa Tenggara Barat

\section{Introduction}

The year of 2018 would be an 'expensive and a blessing' year for Indonesia, if it is able to introduce the enormous economic, natural, cultural, and religious values in the world economy views. Based on data from State of the Global Islamic Economy 2017-2018 (Rafiq A. Tschannen 2018) that the Muslim market share toward the global Sharia industry from the expenditure side reached at $11.9 \%$ in 2016 and is projected to increase from USD 2.006 billion to USD 3.081 billion by 2022 . Indonesia should be able to take advantages and participate in the midst of a large market share of the Muslim World. As a country with the largest Muslim population, the current Muslim population in Indonesia is more than 226.2 million. Is is the largest Muslim population in the world, of course, naturally gives positive energy to economic and business movements based on sharia principles.

Indonesia has many existing institutions engaged in sharia economics, finance and business shari. In the area of sharia economy 
and finance, Indonesia has 13 Sharia Commercial Banks (BUS) and 1.822 offices with 49.971 workers. The sharia financial transaction movement was also supported by the emerging sharia state-owned enterprises (BUMN) and 348 Sharia Business Unit (UUS) offices with 4.834 workers. Indonesia also has 168 Sharia People's Financing Banks (BPRS) with 458 offices and was supported by 4,865 resources who are experts in sharia economics. The number of Indonesia sharia financial assets has increased from USD 47.6 billion in 2016 to USD 81.8 billion in 2017 or improved the rank from $9^{\text {th }}$ to $7^{\text {th }}$ grader in the world. As of May 31, 2018, total sharia financial assets continued to increase to USD 82.33 billion.

The sharia economic movement in Indonesia is not only in the mainstream sector of sharia economics and finance, but also infiltrates the real business that directly impacted the public. Indonesia has many Sharia Cafes; there are 730 Sharia Hotels with an average growth of $10 \%$ every year; there are 10 Sharia Hospitals; and there are 3 shariabased cemeteries such as one Sharia Cemetery in Semarang, Central Java and two in West Java. The sharia economic movement also exists in the wider economic areas, namely the emerging of two Sharia Traditional Markets located in Surabaya, East Java and West Lombok at West Nusa Tenggara. Sharia values also cover sharia tourism, such as two Sharia Beaches located in Lombok West Nusa Tenggara and Banyuwangi in East Java, sharia cultural destination in Aceh, sharia culinary destination in West Sumatra etc. In the millennial era and development of financial information and technology, Indonesia is also developing a market place in sharia fintech. (Dakhoir 2018)

The various Sharia institutions and Islamic economics above become strong evidence that Indonesia has succeeded in developing 
and benefiting from the emerging sharia industry both sharia economy and finance, including sharia food and beverage industry, sharia fashion, cosmetics, and pharmaceutical industries that have been formulated lately. Specifically, for sharia travel and tourism, Indonesia has 13 sharia tourism destinations spread across Aceh, West Sumatra, Riau, DKI Jakarta, West Java, Central Java, East Kalimantan, DI Yogyakarta, East Java, South Sumatra, Lombok-West Nusa Tenggara,Banten, and South Sulawesi. According to Global Muslim Travel Index (GMTI) 2018, Indonesia is ranked as the second sharia tourism destination in the world. As a result, the track record of sharia industry that has touched various sectors has given a positive stigma that Indonesia has become one of the centers for developing the largest sharia economic institutions and the sharia center of the world. (Mastercard and Crescentrating 2018, 18)

Furthermore, the development of Indonesian tourism is moving towards a positive trend. In 2015 this sector was able to contribute to GDP (Gross Domestic Product), foreign exchange and market works. National GDP in 2015 reached 10\% with the highest nominal in ASEAN. National tourism GDP growth grew by $4.8 \%$ with an upward trend of $6.9 \%$. This is quite high when compared to the agriculture, manufacturing, automotive and mining sectors. Foreign exchange tourism has 1 million dollars in 2015 with a GDP reaching 1.7 million dollars. This sector also provides a fairly good contribution in opening employment. This sector is able to contribute up to 9.8 million job markets. (Subarkah 2018a, 91)

In international scope, world tourism faces various development trends. One of them is sharia tourism. This type of tourism is a tourism segment providing basic necessities needed by 
Muslim tourists in accordance with Islamic law. The knowledge of Halal tourism concept and components are pertinent to industry players alike in developing Halal tourism infrastructure and facilities, halal travel packages, and halal travel activities. It will also help them design specific messages for marketing communication in order to attract Muslim tourists.(Battour and Ismail 2016, 150) Nevertheless, sharia tourism facilities can also be enjoyed by non muslim tourists, because as a whole the core facilities intended only refers to food and beverage facilities with sharia labels, sharia restaurants, and sharia hotels.

Referring to those developments, it is very important for Indonesia to develop sharia tourism. One of the areas considered to be a very appropriate for developing sharia tourism is West Nusa Tenggara, which has a vision of 'Faithful, Cultured, Competitive and Prosperous'. The word 'faith' at the beginning vision describes a picture of West Nusa Tenggara people, who uphold their religion and carry out their daily lives in accordance with their respective religions. Considering that majority of West Nusa Tenggara people are Muslim, this area is suitable for developing sharia tourism. As a result, West Nusa Tenggara received award from World Sharia Travel Summit held in Abu Dhabi for two consecutive years (2015-2016) with predicate: the world's best sharia travel destination, the best sharia honey moon tourism in the world, and the best sharia travel page. (Subarkah 2018a, 93)

To be able to realize and accommodate sharia economy development and especially the best sharia tourism in the world, Indonesia must be able to play an important role in adjusting ideas and fast-developing conditions. Although many experts positioned the importance of law in economic development of a nation, but until now 
the President has not made legal development yet as a top priority to sustain economic development. At present, the development carried out seems to be allowed to flow without orientation. This becomes the main weakness of legal field. One of the critical factor faced by economic parties in Indonesia is the issue of legal uncertainty. Legal certainty is needed to calculate and anticipate risks. Even for a country, legal certainty is one of the factors that greatly supports the economic endurance of a nation. The government is responsible for providing legal certainty to economic actors, by responding and following up on the wishes of economic actors. So That in the future the law is expected to be able to play its role as a guiding factor, guide and create a conducive climate in economic field, especially in industrial field of Sharia and in tourism-based sharia.

\section{Method}

Sharia tourism development research to foster regional economic growth (a study on West Nusa Tenggara sharia tourism) was a normative legal research (Sudikno Mertokusumo 2010, 27) In the framework of legal perspective, it meant explaining, strengthening, or testing a provision regarding estabishing legal and developing sharia centers in Indonesia. (Waluyo 2008, 75) More specifically, the study focused on ideal values, which were a reference in the formation, regulation, and legal development. (Yesmil and Adang 2013, 89) The study belonged to a field research. The preliminary study used empirical data or other primary data. The reseachers focused on library literacy. The study conducted through literature as written sources. It was the first step to prepare research framework and strengthened 
theoretical studies. (Sunggono 2012, 86) Data were collected using a review of relevant references and issues relating to the problem being investigated, specifically developing sharia tourism to promote regional economic). (Soekanto and Mamudji 2010, 114)

The study approach used on developing sharia tourism to foster regional economic growth in the context of legal policy and the sharia economics. (Marzuki 2010, 94)

\section{Result and Discussion}

\section{A. Road Map for Sharia Tourism Development in West Nusa Tenggara}

Road map for developing Sharia tourism in West Nusa Tenggara was carried out by West Nusa Tenggara Regional Government through the Tourism Department. One of the efforts of Regional Government in developing sharia tourism was the regulation of sharia tourism in local regulations. Such efforts were made to ensure the implementation of Sharia tourism in West Nusa Tenggara.

The choice of West Nusa Tenggara as a sharia tourism destination in 2015 encouraged Regional Government to conceptualize sharia tourism. The conceptualization is expected to be well-received by tourists, business people and local government itself. Fortunately, since the beginning, West Nusa Tenggara was a tourist destination in Indonesia. Therefore, the local government did not need too much worry that the area was not visited by tourists. When there was a tendency for an increase number of Muslim tourists visiting a tourist destination needed to be captured as an opportunity to increase the country's foreign exchange through tourism, especially if Muslim tourists had their own uniqueness, the desire to travel while continuing to carry out their religious teachings, such as praying, eating Sharia

122 | VOL. 9 NO. 1 JUNE 2020 
food, avoiding alcoholic beverages, privacy and convenient with family when traveling. The desire to carry out religious teachings in travelling is mentioned by the Global Travel Index as the basic needs of world Muslim tourists. In order not to misunderstand with other tourists about the integration concept of basic needs based on religion in travelling, Regional Government has chosen to use the term sharia tourism rather than Islamic tourism. (Fahham 2017, 70)

It can be seen from sharia tourism regulations issued by regional government. The term sharia tourism is already well known in global tourism. The terms such as sharia tourism, Islamic tourism, and Muslim family friendly were terms that had been known in several countries such as Japan, Thailand, Turkey, South Korea, Australia and the United Kingdom. Having said that, Halal tourism is one of the new phenomena emerged from the growth of Halal industry. As Halal matters advancing tourism industry, many Muslim and non-Muslim countries are set to capture the Muslim tourists market by providing the tourism products, facilities and infrastructures to cater their needs. (Samori, Md Salleh, and Khalid 2016, 2)

In case of West Nusa Tenggara, the development of sharia tourism is directed towards family tourism by accommodating the basic needs of Muslim tourists and reinforced by religious and cultural tourism. Sharia tourism development encouraged Regional Government to accelerate sharia certification for restaurants and hotels, improvement of road infrastructure and modes of transportation. In addition, sharia tourism in West Nusa Tenggara provided the issuance of regional regulations, which becomes legal references in the implementation of sharia tourism. (Fahham 2017) 
The implementation of sharia tourism in West Nusa Tenggara province was actually not much different from the concept of conventional tourism in general. Both were natural tourism (ecotourism), shopping tourism, educational tourism, culinary tourism, culture, hunting tourism and other types of tourism. Specifically, the only difference was the presence of time limit, which must be existed in sharia tourism regulation. Related to the new halal limit, Mr. Alfi, head of the tourism product section of Tourism Department of West Nusa Tenggara explained:

"What should be known is that West Nusa Tenggara adheres to the halal number 1 . The indicator is a Muslim friendly-system that makes it easier for Muslims, to pray, anywhere anytime in Lombok with comfort an certainty. In fact, the Tourism Department does not need to build many to worship facilities, as in almost every corner of Lombok one can find prayer rooms and mosques, which we say are more than sufficient for areas along our tourist route. Likewise, in tourist objects, although in remote areas, the mosque and the availability of facilities for worship must be there. At a glance there are no specific differences associated with it (sharia tourism). Many tourist sites have separated halal tourism from conventional tourism, only a few industries/service providers fully implement it. Most are still mixed, as long as there is a place of worship according to the Halal 1 concept. Halal tourism that applies fully or Halal 2 usually applies based on Islamic boarding, which is managed by individuals or the community, for example, separate bathing pools, this is for men bathing pools and female bathing pools."

Furthermore, Mr. Alif, the Head of Section for Education and Training who previously to be a staff of sharia tourism division, underlined about sharia tourism 1:

"Actually many people misunderstood toward the concept of sharia tourism. Most people think that sharia tourism is applied in accordance with sharia requirements. For example, applying sharia on tourism at the beach means that people, places and so on must comply with Islamic law. People have to dress in Muslim fashion, they should not reveal their hair and bodyparts as it must be covered, everything else must also match the sharia law.

For example, West Nusa Tenggara is applying Halal 1 system, which means in order to making it easier for tourist-especially Muslim tourist-the area must provide facilities for ablution and pray. On top of it, food must also be provided in accordance to sharia requirement. 
The next sharia tourism concept is Halal 2, which is applied gradually and cannot be implemented directly. This concept is called Sharia tour. The managers must really understand sharia studies; the visitors must wear the clothes according to sharia rules and their personal characteristics must also be completely correct according to the sharia principles. As for the Halal, we are using it gradually".

From such above statement, it can be understood as a separate strategy done by provincial government of West Nusa Tenggara in order not to distinguish between conventional tourism and sharia tourism in West Nusa Tenggara. Specifically, it is to regulate the ease of obtaining facilities for worship, and to provide halal food regulation in accordance to sharia point of view. This can be understood because the concept of sharia tourism adopted in West Nusa Tenggara Barat uses the Halal 1 concept.

Furthermore, the concept of halal tourism industry in regional regulation is that the sharia tourism industry is tourism businesses selling tourism services and productsbased on sharia principles in National Sharia Board of Indonesian Ulema Council'sperspective. The Sharia tourism industry consists of accommodation, travel agencies, restaurants and SPA. Management of sharia tourism industry follows National Sharia Board of Indonesian Ulema Council regulations. For example accommodation must be in accordance with sharia standards and obtain certification from National Sharia Board of Indonesian Ulema Council. The sharia standards cover aspects of products, services and management. If the management standards do not meet the sharia, then the least any available accommodation can provide is adequate facilities for having ablution, available facilities that make it easy to worship, available Sharia food and drinks, facilities and a safe, comfortable and conducive atmosphere for families and businesses, as well as maintaining sanitary hygiene and clean environment. 
Developing Sharia Tourism in ....

From the management view, sharia tourism travel agents must understand the management of sharia tourism destinations; provide information on sharia tourism packages and tourist behavior at Sharia tourism destinations; organize travel packagesin accordance with Sharia tourism criteria according to standard operational procedures issued by National Sharia Board of Indonesian Ulema Council. Tour guides at sharia tourism travel agents must understand and be able to carry out sharia values when carrying out their duties, having good morality, communicative, friendly, honest, and responsible, having polite performance in accordance with Islamic values and ethics and providing Islamic values during the tour. (Pemerintah Provinsi Nusa Tenggara Barat 2016) Those regulations explicitly covers, first, everything should be suitable with sharia standard consisting of products, services and management. This sharia standard is called the halal 2. Furthermore, secondly, if the management standard does not meet the sharia, then at least there are available adequate facilities for having ablution, available facilities that make it easy to pray, available sharia food and drinks, facilities and a safe, comfortable and conducive atmosphere for families and businesses, and maintaining sanitation and clean environment. Standards that do not fully meet these sharia standards are called halal 1.

This is a form of choice from West Nusa Tenggara government to become a tourism product called sharia tourism product of Halal 1 concept offered by West Nusa Tenggara government, so that it can be accepted by all groups. Promotion in Sharia tourism sector includes providing information on investment opportunities in tourism area, increasing investment promotion in domestic and foreign tourism sector, and increasing synergy of tourism investment promotion with 
related sectors. Provincial Government also carries out marketing and promotion of Sharia tourism implementation. (Saputra 2017, 56)

For developing sharia tourism in West Nusa Tenggara, both in the form of natural tourism (ecotourism: such as mountains, waterfalls, beaches, etc.), shopping tourism, educational tourism, culinary tourism, culture, hunting tourism and other types of tourism. For developing sharia tourism or conventional tourism, with the change of a new leadership era, a new governor should direct the aspect of tourism, such as cultural aspects or village tourism. One of the missions of the new governor, Bang Zul-Umi Rohmi, is to create a Tourism Village. It is clearly illustrated from the program that the goverment prepare one billion incentive funds to potential villages to be developed into Tourism Villages. This step is very strategic in order to develop the continuation of sharia tourism existence. The program is called "99 glorious West Nusa Tenggara Tourism Villages". To make it easier to declare, an elected governor makes its roadmap planning.

This is the target of future development in 2019-2023 sharia tourism, a type of cultural tourism with local wisdom. The target must be reached as many as "99 tourist villages" during the period. Sharia tourism in the form of a tourist village is expected to be a bridge between tourism and local wisdom from local residents. Tourism village is a tourism resort that is friendly to Islamic culture. Its cultural characteristics is different from tourism in general. A village tourism as a community entity has some uniqueness with the entity of urban community, which tend to blend based on expertise specifications. Villages as uniform groups, where in Indonesia are culturally often identified as rural communities with a touch of intermediate industry, have relatively high social control mechanisms. 


\section{Figure I.}

Roadmap Planning 99 glorious West Nusa Tenggara Tourism Villages

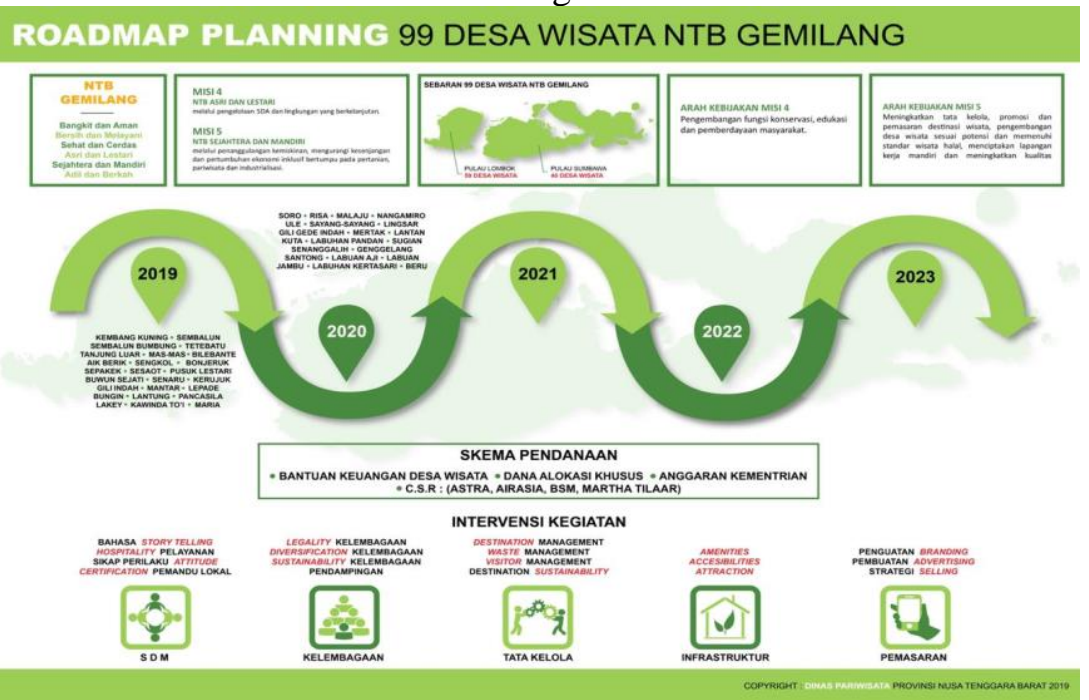

That social control will become the mechanism of acculturation of values, norms based on religion and local wisdom, from the existence of conventional tourism to sharia tourism. However, tourism if viewed from sociology of tourism also studies the mutual interactions between tourists and local people. This interaction is observation variable that makes it possible to assess whether there is an interrelated relationship between local communities and migrants (tourists). In this context, Tourism Village can be formatted in such a way as in order to provide a different color (performance) to the visiting tourists.

If tourism has been criticized for a long time because it gives an influence that is not suitable with civilization and morality of local community, then the Tourism Village that has been designed in such a way can be a turning point in the development of tourism that is consistent with social norms. This has been practiced in several 
tourism villages that researchers know about, such as the Sasak Ende Village tour. Sasak Ende tourism village is a village that provides services in accordance with local standards and sharia's law. In the village offers the values of local wisdom that is owned to be served to visiting tourists.

Tourism village is typical, because the villages perform different things by keeping legacy in keeping local cultural customs by eliminating the elements of polytheism. The main attraction in village is the uniqueness of residential buildings where-floors have been cleaned using warm cow dung. This is an expression of their gratitude

for livestock, which always helped them in plowing the harvest. Researchers understand well that the local community is the subject of all its uniqueness. With interactive model in Tourism Villages designed in such a way, there is actually a sharia tourism breath. Tourism that is not counterproductive to local cultural customs, so that tourism can be understood as a way to provide something valuable to guests who come from developed countries (Westerners in general). Other Tourism Villages that are widely planted by Governor and vice governor Bang Zul-Ummi Rohmi also apply standard operational procedures (SOP) of local wisdom, which of course with a variety of performance so that tourism is not accused continuously of being the source of a moral decadency, so tourism is not merely complained but becomes a medium to bulldoze degradation of morality itself.In addition to the declared sharia tourism village, local government also encourages conventional tourism industry to provide: Qiblah directions in hotel rooms, information on the nearest mosque, places of worship 
for Muslim tourists and employees, separate facilities for men and women and easy access to have ablution.

Furthermore, conventional tourism in general and Sharia tourism are side by side, as a manifestation of product model or choice that can be chosen by tourists. Therefore, sharia tourism destinations that do not kill other tours also become a vehicle for a particular choice of product models in West Nusa Tenggara. They are considered successful in attracting local, national and foreign tourists to enjoy the overall tourism products in West Nusa Tenggara Province. Furthermore, in terms of development carried out by government of West Nusa Tenggara, it develops the continuation of the existing Sharia tourism by launching 99 sharia tourism villages having local wisdom.

\section{B. Impact of Developing Sharia Tourism on West Nusa Tenggara Income}

Indonesia's tourism is the fastest growing tourism sector and became the largest economic sector due to its contribution to the country's second largest foreign exchange after the palm oil industry. The palm oil, reached USD 15,965 Billion in 2016 while tourism ranked second reaching USD 13.568 Billion in 2016. A year earlier, in 2015 the tourism sector was in the fourth position, which contributed to foreign exchange with achievements of USD 12.225 Billion after Oil and Gas (USD 18,574 Billion), Palm Oil (USD 16,427 Billion), Coal (USD 14,717 Billion). This also makes it a leading sector for several reasons, namely: the number of destinations and increased tourism investment makes it a key factor in creating jobs, infrastructure, and business development, to national income from exports. Indonesia projects that in 2019 this sector can increase Gross Domestic Product (GDP) by 15 percent, with a visit of 20 million 
foreign tourists, 275 million trips by archipelago tourists, and is expected to absorb up to 13 million workers.

Foreign policy by conducting public diplomacy through developing Sharia tourism rationally wants to fulfill national interests. In this case achieving economic interests by attracting Muslim tourist visits as the main target market. Tourism and economy have a strong connection, as the development of tourism in an area. It enables development of economy in that area. Relations between the two are complementary each other. Economy will grow if it is supported by developing advanced tourism, especially for businesses around tourist destinations, both small, medium, and large businesses. According to Coopermodel, there are three elements related to tourist economy, namely:

1) consumers in this case are tourists;

2) circulated currency as an element in economic transactions;

3) available of goods and services from the economic sector.

An interesting hypothesis put forward by Muhammad Afdi Nizar (Muhammad 2000) about the relationship between tourism and economic causality, namely:

1) economic growth is supported by tourism, therefore economic growth is influenced by tourism development (tourism-led economic growth hypothesis);

2) tourism is supported by economy, so the development of tourism is influenced by economic growth (economic-driven tourism hypothesis);

3) both (economy and tourism) have the benefit each other and are bi-directional (reciprocal causal hypothesis). 
Developing Sharia Tourism in ....

Nizar believes that there are two things that build the relationship between tourism and the economy, namely:

1) Tourism gives an impact on the economy because it can create jobs, affect income, balance of payments, foreign exchange earnings from several things, such as tourist spending, tourism place development, import and export of goods and others;

2) Tourism can be a stimulus effect for certain products and can form communities expected to move regional economy in a positive direction by creating new jobs and increasing income for the region.

According to Cohen, the impact of tourism on the economy can be a source of foreign exchange, a source of community income, income for government, employment creation, an influence on prices and tariffs, an influence on the distribution of benefits, an influence on management and ownership, and can certainly affect development. There are several things that can affect tourism-related income, including the level of consumption or expenditure, distance from tourist attractions, length of service and the number of tourists visiting. Meanwhile, Dian Dinta Herlambang was quoted subarkah (Subarkah 2018b) believes that there are at least four things that can be influenced by tourism on economic conditions in tourist attractions, namely: a) type of work, community has a job, such as street seller, then becomes an employee at a tourist site (ticket entry, security supervisor, rubbish management and others); b) community income will certainly also feel the effects of tourism development; c) the growth of other sectors in the vicinity of tourist attractions, the establishment of stalls, there are inns owned and managed by the surrounding community; d) food and mineral stalls in tourism sites will change in prices that can be a benefit 
for traders. The influence of tourism development on the economy can change a number of things, namely: change in type of work, community income, division of labor, as well as employment and entrepreneurship opportunities.

At whole, tourism has an important role in increasing economic sector, Local businesses will grow; jobs can be created; income is also diverse. This makes tourism greatly affects regional

economy. Therefore, economy and tourism have a very strong and interrelated relationship each other. Tourism can be used as an economic driver. Tourism areas are resistant to economic crises, easy and inexpensive to develop. Economy becomes an element in helping the development of tourism, especially Sharia tourism. It is expected to be a milestone in economy of West Nusa Tenggara region with potential for global Sharia tourism that continues to increase as an economic alternative driver by increasing tourism visits and investment to West Nusa Tenggara, which makes the Middle East a tourist target market.

To welcome the tourism potential, Indonesian Government made tourism as a major sector in national development beside agriculture/plantations, oil and gas, and mining, such as making tourism development plans for 2015-2019. In 2014 the number of foreign tourist arrivals reached 9 million people, and expected in 2019 to reach 20 million people. Meanwhile, domestic tourists who travel in 2014 reached 250 million people, were expected in 2019 to reach 275 million people, with the hope of influencing growth National Gross Domestic Product (GDP) in 2014 reached 4.2\%, expected in 2019 to reach $8 \%$. It was also expected to contribute to foreign exchange in 
Developing Sharia Tourism in ....

2019 to Rp. 240 trillion while in 2014 only reached Rp. 120 trillion. It was hoped that inclusive growth can increase local businesses in tourism and certified labor. (Ekonomi 2014, 2)

Data obtained from West Nusa Tenggara Tourism Office and Bank Indonesia related to the development of sharia tourism also tent to a positive increase in economic growth. It was reported that the economic growth of this region without mining sector in 2016 reached

$5.72 \%$ / year increasedin 2017, it reached $7.10 \%$ / year and in 2018, despite the earthquake, it continued to increase to $7.23 \%$ / year. (Indonesia 2018)

Visits of foreign tourists to West Nusa Tenggara have also increased sharply. Tourists from Middle East in 2014 reached 405 tourists, up to 935 tourists in 2016, followed by tourists from Malaysia reached 502 people in 2014, reaching 1.719 tourists in 2016 and flights from Malaysia, which are usually dominated by labor, now have a positive trend filled with tourists from Malaysia.

Various foreign investors also began to arrive to observe the development of tourism in West Nusa Tenggara, such as 15 Australian investors coming to inspect several points in the Mandalika Special Economic Zone (KEK) with an area of 1.200 hectares. Besides Australia, the main target was investors from Middle East. Maarij Capital Company from Saudi Arabia was interested in investing in Sharia tourism in West Nusa Tenggara, especially in Mandalika SEZ, which was prepared 250 hectares for sharia tourism (Subarkah 2018b, 65-67)

The development of Sharia tourism also showing a positive increase in economic growth in West Nusa Tenggara province. It can 
be seen from data released by the Tourism Office and Bank Indonesia, which shows the economic growth of this region without mining sector in 2016 reached $5.72 \%$ / year increased in in 2017 it reached $7.10 \%$ / year and in 2018 despite the earthquake it continued to increase to $7.23 \%$ / year.

\section{Legal Policies in Developing Sharia Tourism in West Nusa Tenggara}

Based on the research findings on legal policies in developing Sharia tourism in West Nusa Tenggara, it can be classified in the following description. The ideas of West Nusa Tenggara Governor Regulation No. 51 of 2015 concerning Sharia Tourism and Provincial Regulation number 2 of 2016 concerning Sharia Tourism, can be found on the philosophical basis of thought reflected in the basis of consideration.

The idea as a philosophical basis of Governor Regulation No. 51 of 2015 concerning Sharia Tourism confirms that:

a. West Nusa Tenggara is one of Sharia tourist destinations in Indonesia. Therefore, Regional Government and all stakeholders must prepare facilities and tourism infra structure that meets Sharia Tourism in the tourism industry in the district;

b. to provide security and comfortable service to tourists so that they enjoy the travelling safely, halal, and can also experience ease in travelling in accordance with the business concept of Sharia tourism. Concept of sharia tourism as an integrated concept Sharia values into tourism activities by providing appropriate facilities and appropriate services based on sharia provisions, it needs to be regulated its management policy; 
Developing Sharia Tourism in ....

The implied and explicit meaning in the basis of consideraton confirms that the local government and all stakeholders to integrate sharia values operationalized into the design of facilities and infra structure that lead to security and comfortability in providing services to tourists coming to West Nusa Tenggara. Meanwhile, the idea as a philosophical foundation in West Nusa Tenggara Provincial Regulation number 2 of 2016 (Pemerintah Provinsi Nusa Tenggara Barat 2016) concerning Sharia Tourism confirms that:

a. Tourism is one aspect of economic development, which is able to accelerate development regional economy and community welfare;

b. Tourism industry stakeholders, both government, Indonesian Ulema Council, private sector, and all community elements work together to develop a business Sharia Tourism;

c. West Nusa Tenggara is asone of the tourist destinations in Indonesia. Therefore, every industry stakeholder tourism must prepare tourism facilities and infra structure, which meets sharia tourism;

d. Sharia Tourism business is a concept integrating sharia values into tourism activities by providing appropriate facilities and services appropriate with sharia provisions;

The contents of implied and explicit ideas oriented towards economic development activityat West Nusa Tenggara Province are believed to develop the tourism industry potential in general. Besides, Sharia tourism choices were developed together by all stakeholders and well-coordinated among Government, Indonesian Ulema Council, private sectors and all element communities, working together to develop Sharia Tourism business. Through the fulfillment program of facilities and infra structure as a result of integration of sharia values in 
facilitating security and comfort-based services for Muslim tourists in particular. This is in line with the aims and objectives of developing tourism industry as regulated in Article 2, which emphasizes:

The purpose of regulating Sharia Tourism in this Regional Regulation is to provide security and convenience of servicefor tourists in order that they enjoy tourist visits safely, Sharia-based and can also get facilities for touristsand managers in tourism activities.

\section{Article 3:}

The purpose of regulating Sharia Tourism is as a guideline for tourism management in providing Sharia Tourism services to tourists. The issuance of Provincial Regulation number 2 of 2016 concerning Sharia Tourism as a higher legal source and completing Governor Regulation No. 51 of 2015 concerning Sharia Tourism. (Berita Daerah Provinsi Nusa Tenggara Barat 2015)

West Nusa Tenggara Provincial Regulation number 2 of 2016 concerning Tourism has a norm integrating sharia values in arranging the Conventional Tourism Industry as regulated in Article 11 Chapter V on Tourism Industry Part One about the Conventional Tourism Industry confirms that:

Conventional tourism industries are tourism businesses selling tourism services and products that are not basedon sharia principles.

1. The conventional tourism industry as referred to in paragraph (1) must provide:

a. Qibla direction in hotel rooms;

b. closest mosque information;

c. worship placesfor Muslim tourists and employees;

d. information on Sharia / non-Sharia products;

e. a separate ablution place for men and women;

f. supporting facilities for praying; and

g. a separate toilet for men and womenand makes it easy to have ablution.

\section{Article 11}

Above regulates and provides space in order that in managing conventional tourism industry remains to provide services to tourists by providing Sharia-based facilities. Specific regulation regarding Sharia tourism industry is regulated in Article 12, Article 17 in Chapter V concerning Tourism Industry. Part Two on Sharia Tourism Industry Section, Paragraph 1 confirms that Sharia tourism industry is tourism businesses selling tourism services and products, which are based on sharia principles as stipulated by National Sharia Board of Indonesian Ulema Council.

The content of Article 12 
Accommodates the Fatwa of the National Sharia Council-Indonesian Ulema Council No: 108 / DSN-MUI / X / 2016 Regarding Guidelines for Organizing Tourism Based on Sharia Principles. Then, it is elaborated in the NTB Provincial Regulation Number 2 of 2016 concerning Sharia Tourism, as follows: (MUI 2016)

Article 13

(1) Sharia Tourism Industry as referred to in Article 12 consists of:
a. accommodation;
b. travel agencies;
c. restaurants; and d. SPA;

(2) Management of Sharia tourism industry follows the stipulations as determined by National Sharia Board of Indonesian Ulema Council.

Article 14

(1) Sharia Tourism must have accommodation according to Sharia standard,

(2) Sharia standards as referred to in paragraph (1) after obtained certification from National Sharia Board of Indonesian Ulema Council.

(3) Sharia standards as referred to in paragraph (1) include aspects:
a. products;
b. services; and
c. management

(4) In case of sharia standards as referred to in paragraph (2)has not been fulfilled yet, the accommodations have at least fulfilled the following:

a. proper facilities for having ablution;

b. available facilities that make it easy to worship;

c. sharia foods and drinks available;

d. available facilities and a safe, comfortable and conducive atmosphere for familiesand businesses; and

e. keep on sanitary and environmental cleanliness.

Article 15

(1) Food and beverage providers in Sharia Tourism cover restaurants, bars, cafes and catering services.

(2) Food and beverage providers should have Sharia certified and must guarantee the Sharia food/ drinks served, starting from the supply of raw materials to delivery process proven by Sharia certificate.

(3) In case of Sharia certificate has not been fulfilled yet, each provider of food and drink must include the announcement of Sharia/ nonSharia for every type of food / drink; and keep healthy and clean environment. 
(4) Sharia food and drinks as referred to in paragraph (2)according to the standards set by National Sharia Board of Indonesian Ulema Council.

Article 16

Every businessman of SPA, Sauna and Sharia Massage should provide:

a. separate treatment rooms for men and women;

b. mind therapy and physical therapy do not lead on sharia violations;

c. male therapists specifically for men and female therapists specifically for woman; and

d. facilities that make it easy to pray.

Article 17

(1) Every Sharia SPA, Sauna and Griya massage is obliged to use official Sharia logo products.

(2) Products bearing the official sharia logo as referred to in paragraph (1)among others:
a. spice ingredients;
b. scrubs;
c. face mask;
d. aroma therapy; and
e. facial, hair, hand and nail care ingredients.

The brief description related to the ideas and Province Regional Regulation number 2 of 2016 concerning sharia tourism places West Nusa Tenggara Regional Government as the first region that has a Sharia Tourism Regulation in Indonesia. The regional regulation is aimed as a guideline for tourism managers in providing sharia tourism services to tourists, and providing security and comfortable services to tourists in order that they enjoy the visits safely based on sharia.

\section{Conclusion}

In terms of the sharia tourism road map carried out by government of West Nusa Tenggara, it is aimed to develop the continuation of existing sharia tourism by launching 99 sharia tourism 
villages with local wisdom. The development of sharia tourism, whichis done by presenting itself as a sharia tourist destination that does not turn off other tourism and is also a vehicle for a particular choice in West Nusa Tenggara, is considered successful in attracting foreign tourist arrivals especially tourists from Muslim countries and attracting investment.

Developing sharia tourism also tends to a positive increase in economic growth in West Nusa Tenggara, at least as seen from data released by the West Nusa Tenggara Tourism Office and from Bank Indonesia, which states that economic growth in this region without mining sector in 2016 reached 5.72\% yearly increased in in 2017 it reached $7.10 \%$ and in 2018 despite the earthquake it continued to increase to $7.23 \%$. Sharia tourism in terms of legal policies in West Nusa Tenggara already has strong legal legitimacy, so that it can guarantee legal certainty in developing sharia tourism destination. Besides, sharia tourism destination in West Nusa Tenggara had appropriate policy directions in their ideas, strongly supported by policies, and implemented gradually.

\section{References}

Battour, Mohamed, and Mohd Nazari Ismail. (2016). "Halal Tourism: Concepts, Practises, Challenges and Future." Tourism Management Perspectives 19: 150-54. http://dx.doi.org/10.1016/j. tmp.2015.12.008.

Berita Daerah Provinsi Nusa Tenggara Barat. (2015). Peraturan Gubernur Nusa Tenggara Barat Nomor 51 Tahun 2015 Tentang Wisata Halal.

Dakhoir, Ahmad. (2018). "Indonesia Tuan Rumah Annual Meeting IMF 2018, "Selamat Datang di Pusat Halal Dunia." Tribun Kalteng.com. https://kalteng.tribunnews.com/2018/07/26/opini-

140 | VOL. 9 NO. 1 JUNE 2020 
indonesia-tuan-rumah-jelang-annaul-meeting-imf-2018-selamatdatang-di-pusat-halal-dunia.

Ekonomi, Deputi Bidang. (2014). Pembangunan Pariwisata 20142019. Jakarta.

Fahham, A. Muchaddam. (2017). "Tantangan Pengembangan Wisata Halal Di Nusa Tenggara Barat." Aspirasi 8(1): 65-79.

Indonesia, Data Bank. (2018). Kajian Ekonomi Regional, Laporan Perekonomian Provinsi Nusa Tenggara Barat.

Marzuki, Peter Mahmud. (2010). Penelitian Hukum. Jakarta: Kencana.

Mastercard, and Crescentrating. (2018). "Global Muslim Travel Index 2018." In Mastercard-Crescentrating, Singapore: MastercardCrescentrating.

Muhammad, Afdi. (2000). "Pengaruh Pariwisata Terhadap Pertumbuhan Ekonomi Di Indonesia." Jurnal Kepariwisataan Indonesia 6 (June):195-211. https://ideas.repec.org/p/pra/mprapa /65628.html.

MUI, Dewan Syariah Nasional. (2016). "Fatwa Dewan Syariah Nasional-Majelis Ulama Indonesia No: 1 08/Dsn-Mui/X/2016 Tentang Pedoman Penyelenggaraan Pariwisata Berdasarkan Prinsip Syariah." : 6-9.

Pemerintah Provinsi Nusa Tenggara Barat. (2016). Peraturan Daerah Provinsi Nusa Tenggara Barat Nomor 2 Tahun 2016 Tentang Pariwisata Halal. https://jdih.ntbprov.go.id/?q=content/perda-no2-tahun-2016.

Rafiq A. Tschannen. (2018). "Outpacing the Mainstream: Islamic Economy Food and Lifestyle Sector Expenditure to Reach US\$3 Trillion by 2022." The Muslim Times. https://themuslimtimes.info /2018/04/16/outpacing-the-mainstream-islamic-economy-food and-lifestyle-sector-expenditure-to-reach-us3-trillion-by-2022/ (September 12, 2018).

Samori, Zakiah, Nor Zafir Md Salleh, and Mohammad Mahyuddin Khalid. (2016). "Current Trends on Halal Tourism: Cases on Selected Asian Countries." Tourism Management Perspectives 19: 131-36.

Saputra, Lalu Ari. (2017). "Konsep Pariwisata Halal Di Nusa Tenggara Barat (Studi Komparatif PERDA Provinsi NTB No. 2 Tahun 
Developing Sharia Tourism in ....

2016 Tentang Pariwisata Halal Dan Hukum Islam.” Universtas Islam Negeri Sunan Kalijaga Yogyakarta.

Soekanto, Soerjono, and Sri Mamudji. (2010). Penelitian Normatif. Jakarta: Rajawali Press.

Subarkah, Alwafi Ridho. (2018a). "Diplomasi Pariwisata Halal Nusa Tenggara Barat." Intermestic: Journall of International Studies 2(2): 188-203.

Subarkah, Alwafi Ridho. (2018b). "Potensi Dan Prospek Wisata Halal dalam Meningkatkan Ekonomi Daerah ( Studi Kasus: Nusa Tenggara Barat )." Sospol 4(2): 49-72.

Sudikno Mertokusumo. (2010). Penemuan Hukum. Yogyakarta: Universitas Atma Jaya.

Sunggono, Bambang. (2012). Metodologi Penelitian Hukum. Jakarta: Rajawali Press.

Waluyo, Bambang. (2008). Penelitian Hukum Dalam Praktek. Jakarta: Sinar Grafika.

Yesmil, and Adang. (2013). Pengantar Sosiologi Hukum. Jakarta: Grasindo. 